\title{
A aparição do demônio na fábrica, no meio da produção
}

\author{
JOSÉ DE SOUZA MARTINS
}

À memória da Carmen Cinira.

RESUMO: A aparição do demônio, várias vezes, durante uma semana, em uma grande fábrica do subúrbio da cidade de São Paulo, em 1956, foi uma indicação de que os fenômenos de demonização podem ocorrer também fora do mundo tradicional e rural dos camponeses. Também os operários da moderna indústria estão sujeitos à invocação do imaginário arcaico para compreender as mudanças tecnológicas na produção. Quando a modernização industrial introduz uma separação radical entre o pensar e o fazer no processo de trabaIho, o imaginário arcaico pode preencher esse vazio para lhe dar sentido: o sentido que sua irracionalidade pode ter.

\section{O olhar do insignificante: memória e testemunhos ${ }^{1}$}

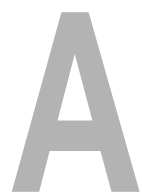

inda adolescente, com 17 anos, fui testemunha de um insólito acontecimento na fábrica em que trabalhava, em São Caetano do Sul, no subúrbio da cidade de São Paulo²: o aparecimento do demônio para várias operárias de uma nova seção onde se fazia a escolha, classificação e encaixotamento de ladrilhos na Cerâmica São Caetano S.A. Durante vários e sucessivos dias, no ano de 1956, há 37 anos, portanto, diversas operárias desmaiaram ao longo da jornada de trabalho. Socorridas, quando voltavam a si alegavam ter visto o demônio a espreitá-las de um canto do imenso salão em que trabalhavam. As visões terminaram quando a direção da empresa decidiu chamar o sacerdote da paróquia vizinha para celebrar uma missa e benzer as novas instalações da fábrica ${ }^{3}$.

Sempre tive presente na memória esse acontecimento. Depois que me tornei sociólogo e professor universitário, pensei em registrar o que havia testemunhado e fazer um pequeno estudo sobre aquela ocorrência. Justamente a sua raridade permite um melhor conhecimento do que é o trabalho e a
UNITERIMOS:

imaginário, demonização, alienação, modernização, relações de trabalho.
Trabalho apresentado no Simpósio de Antropologia Industrial organizado por Eliane Daphy e Oscar Gonzalez no 13응 Congresso Internacional de Ciências Antropológicas e Etnológicas. México (DF), 29 de julho a 5 de agosto de 1993.

Professor do Departamento de Sociologia da FFLCH-USP 
experiência do trabalho na concepção do próprio trabalhador. Meu intuito é o de produzir um documento para a história das relações de trabalho no Brasil e uma contribuição ao estudo das particularidades da vida cotidiana na fábrica. $\mathrm{O}$ acontecimento a que me refiro pode ser metodologicamente examinado como revelador e analisador ${ }^{4}$ de certas características do processo de trabalho em crise. Elas não são, em princípio, imediatamente visíveis para o pesquisador acadêmico que não tem acesso direto e espontâneo às minúcias cotidianas da produção. Ou que o investiga e estuda através da observação de terceiros e informantes. Uma competente antropóloga realizou um estudo sobre a mesma fábrica alguns anos depois, utilizando preferentemente técnicas sociológicas, mas não teve qualquer notícia dos acontecimentos a que me refiro (cf. Macedo, 1979). Isso provavelmente se deveu ao fato de que os próprios operários assimilaram a ocorrência como irrelevante e meramente acidental. Mas se deveu também ao fato de que na sua relação com a fábrica, enquanto objeto de estudo, os cientistas sociais pressupõem, equivocadamente, que a racionalidade da grande indústria não comporta a ocorrência de fenômenos irracionais, prevalentemente dominados pelo imaginário. A mera coincidência de que eu tenha testemunhado os fatos e tenha, depois, me tornado sociólogo constitui, pois, um acidente útil que pode ser encarado como elaboração "a posteriori” de uma situação de observação participante. A sociologia pode legitimamente valer-se de uma orientação como essa para recuperar informações e dados que com mais facilidade, nessa perspectiva metodológica, são usualmente colhidos na investigação antropológica.

Não só é insólito o caso aqui analisado, mas é raro, também, que o sociólogo recorra, de início, a dados de sua própria memória para reconstituir o acontecimento. Em face dessa circunstância incomum, procurei cercar-me de garantias de que essa reconstituição seria feita com objetividade. Quando tomei a decisão de fazer este estudo, redigi um extenso texto registrando o mais minuciosamente possível todas as lembranças que tinha da ocorrência e de suas circunstâncias. Rememorei, também, e anotei detalhadamente todos os momentos do processo de trabalho, desde a chegada do barro das jazidas até a saída dos produtos da empresa. Depois disso, procurei localizar antigos empregados da fábrica para recolher deles referências igualmente minuciosas a respeito do mesmo assunto e a respeito da aparição do demônio. De modo que minhas próprias anotações pudessem ser conferidas e confrontadas com as lembranças que tinham. Entrevistei demoradamente dois engenheiros diretamente envolvidos nos acontecimentos, o antigo chefe da seção do pessoal, o antigo mestre da seção de ladrilhos e o padre que foi chamado para celebrar a missa e benzer as novas seções e as operárias. Várias testemunhas importantes já haviam falecido quando decidi fazer esta reconstituição. Entre elas, o mestre e a contra-mestre da própria seção de escolha de ladrilhos ${ }^{5}$.

$\mathrm{O}$ engenheiro que era diretor da Divisão de Terra Cota, em que se situava a produção de ladrilhos, lajotas e telhas, e que era a pessoa com maior informação e poder de decisão no caso, lembrou-se da ocorrência, tanto da 
aparição do demônio quanto da decisão de chamar o padre. O outro engenheiro lembrava-se das dificuldades técnicas que apareceram com a mudança de tecnologia nas novas seções de produção de ladrilhos, mas não se lembrava do aparecimento do demônio. Um filho do mestre da seção de escolha confirmou-me que seu falecido pai fizera em casa comentários a respeito da ocorrência. O mestre da seção de prensagem dos ladrilhos lembrava-se, também, das dificuldades técnicas da mudança, mas não se lembrava do caso do demônio. $\mathrm{O}$ antigo chefe da seção do pessoal lembrou-se de que o padre fora chamado algumas vezes, mas também não se recordava do caso. E, finalmente, o padre lembrava-se de ter ido duas vezes à fábrica para celebrar missa num altar, diante da imagem de São Caetano, que havia no pátio interno do estabelecimento, a chamado do chefe da seção do pessoal. Mas, também não se recordava do caso do demônio.

Os entrevistados que, como eu, haviam trabalhado na fábrica confirmaram a exatidão de toda a reconstituição que fiz do processo de trabalho na Divisão de Terra $\operatorname{Cota}^{6}$. Acrescentaram detalhes de natureza técnica, inclusive nomes de máquinas e equipamentos, como prensas e fornos, bem como nomes de engenheiros e mestres de seções, responsáveis por vários episódios em última instância relacionados com o do aparecimento do demônio.

Minha reconstituição de memória dos fatos, das circunstâncias, dos equipamentos e dos procedimentos adotados na produção na Divisão de Terra Cota foi completa e detalhada. De modo geral, as entrevistas me mostraram que guardei melhor e mais completa lembrança do acontecido do que os mestres e engenheiros, com exceção do próprio diretor da Divisão de Terra Cota, com quem eu trabalhara diretamente e de quem eu fora office-boy.

Um dos engenheiros entrevistados, e que trabalhou no mesmo escritório técnico em que eu desempenhava essa função, não se lembrava de mim, apesar de eu ter trabalhado ali por mais de quatro anos e ter-lhe prestado serviços pessoais diários na maior parte desse período. Disse-me que fizera um grande esforço para lembrar-se de quem eu era, entre o momento em que lhe escrevi solicitando a entrevista e o momento em que a entrevista se realizou, mas não conseguia localizar-me em sua memória. Ele se lembrava apenas de que "havia no escritório um menino que levava papéis" do diretor da divisão para um dos diretores da empresa. Igualmente, o mestre da seção de prensagem de ladrilhos, que teve contato diário comigo durante todos aqueles anos e apesar de ter o mesmo nome e sobrenome que tenho, não se lembrava de mim.

Essas duas pessoas indiretamente sugeriram-me uma chave importante para decifrar as razões de minha memória minuciosa da fábrica. $\mathrm{O}$ trabalho que eu fazia era irrelevante e não tinha a menor visibilidade no conjunto das complicadas atividades do escritório de engenharia em que eu trabalhava. Localizado no centro do conjunto de edifícios da Divisão de Terra Cota, era o lugar da atividade intelectual que regulava toda a produção daquele setor. Foi, também, o centro nervoso das tensões que ocorreram naquele período em 
função dos vários problemas de ajustamento técnico que surgiram com a inauguração de uma nova seção de prensagem de ladrilhos, um novo forno contínuo ou forno túnel para queima dos materiais e uma nova seção de escolha e embalagem.

O meu trabalho era, justamente, o de fazer coisas pelas quais eu não fosse notado: limpar as mesas e os objetos a cada certo tempo, durante o dia, para remover o pó fino que caía permanentemente sobre tudo e sobre todos; servir café aos engenheiros e aos mestres que por ali passavam, entregar documentos nas seções e nos escritórios, levar recados, chamar pessoas. Todas essas atividades eram completamente irrelevantes para as funções essenciais do escritório da Divisão de Terra Cota. Tanto que todos os entrevistados vinculados à fábrica lembravam-se perfeitamente de nomes e sobrenomes de engenheiros, mestres e contra-mestres e até de alguns operários mais experientes e qualificados. Eram suas atividades que, de fato, davam sentido a um trabalho insignificante como o meu. Na fábrica, o diálogo e o relacionamento era entre qualificações profissionais, entre funções, e não primariamente entre pessoas concretas, com rosto e nome, e isso se tornou muito mais acentuado no momento em que os fatos ocorreram, quando a empresa desenvolveu uma estratégia de despersonalização das ocupações, procurando torná-las impessoais e preferencialmente técnicas.

A fala do engenheiro e do mestre me mostraram que eu pertencia ao grupo de adolescentes que por suas atividades eram pessoas insignificantes no conjunto das relações sociais da empresa. Mas, um insignificante substantivo. Refiro-me aos adolescentes que faziam serviços auxiliares nos pequenos escritórios do interior da fábrica, fora das grandes seções. Essa constatação é importante neste estudo porque naquele período era notória a preocupação com a visibilidade de tudo e de todos no interior da empresa, como mostrarei mais adiante. Excetuados os engenheiros e os mestres e chefes de seções, a ninguém mais era permitido circular fora do seu recinto de trabalho e, até mesmo, do seu posto de trabalho na respectiva seção. Era excepcional a posição de alguém cuja atividade o fizesse invisível e insignificante, especialmente alguém que, em princípio e em razão da própria atividade, tinha acesso praticamente livre a qualquer ponto do estabelecimento e a qualquer um de seus edifícios, inclusive nas seções da Divisão de Refratários, como era o meu caso. Os adolescentes, como eu, podiam ver tudo porque eram funcionalmente invisíveis aos muitos olhos que disfarçadamente, como era necessário, vigiavam o que ocorria no interior da fábrica ${ }^{7}$. Não só porque as pessoas de algum modo, segundo as concepções da época, tinham que estar sob vigilância para que não viessem a fazer aquilo que não estava prescrito em sua rotina de trabalho. Mas, também porque, como em qualquer fábrica, são muitos os perigos que ela encerra. Um pequeno descuido num canto de um setor secundário pode provocar um acidente ou desencadear um incêndio. Foi o que ocorreu na seção velha de prensagem de ladrilhos, quando uma distração do operário encarregado de fundir parafina e outros derivados de petróleo 
para limpeza dos estampos provocou um incêndio que poderia ter levado a uma grande destruição.

Eu tinha um domínio visual razoavelmente completo de todos os procedimentos adotados no processo de trabalho nas várias seções pelas quais ele se distribuía. E porque trabalhava no mesmo escritório dos engenheiros tive, rapidamente, que me familiarizar com toda a nomenclatura dos equipamentos principais, da matéria-prima e dos procedimentos de produção mais importantes, além dos nomes de todos os engenheiros e da quase totalidade dos mestres. A minha inserção insignificante e quase invisível no próprio centro de decisões do conjunto da Divisão de Terra Cota e a minha mobilidade no seu interior por vários anos puseram-me, de fato, sem que eu evidentemente o soubesse, na condição de um etnógrafo espontâneo. Minha memória registrou até mesmo as relações de parentesco que havia entre vários mestres e, também, as dificuldades que tinham para lidar com a cultura letrada e universitária dos engenheiros.

Penso que uma segunda condição de objetividade neste estudo é assegurada pelo fato de que meu caso se situa no âmbito daquilo que Berger denomina "alternação biográfica" - com o passar do tempo, cada um de nós se insere em outras e novas situações sociais, distintas de muitas que constituem a história de nossa vida (Berger, 1972, p.65-77) ${ }^{8}$. Esse deslocamento biográfico nos põe diante de momentos de nossa história pessoal que se tornaram distantes e "externos" para nós, numa relação de certo modo objetiva, como a de um etnógrafo em relação ao grupo que estuda. Nessa relação de "exterioridade" no tempo biográfico, nos casos em que se dá, uma ocorrência como a que examino neste estudo pode, então, ser relembrada e interpretada pelo próprio protagonista, ou pela própria testemunha, a partir de um sistema de significados diverso daquele que deu sentido às relações sociais e aos acontecimentos no momento em que foram vividos. Podemos rememorar a nossa própria vivência do passado a partir de um novo e diferente modo de ver e compreender a vida, definido pelas circunstâncias do nosso presente. Neste caso, concretamente, utilizando o aparato teórico e interpretativo da sociologia.

É possível uma relação objetiva do sujeito com o sujeito quando há a mediação das mudanças biográficas e da ressocialização ao longo da vida. De certo modo, o homem comum está continuamente na situação de etnógrafo amador de suas próprias experiências sociais. Embora ele não possa se dar conta disso, o sociólogo e o antropólogo podem, por seu intermédio, reconhecer e recuperar essa situação em favor da ciência e fazer pesquisa perfeitamente objetiva. Não é isso que de fato acontece num grande número de estudos sociológicos e antropológicos? É evidente que, mais do que ninguém, na maioria dos casos ele tende a rememorar seletivamente aquilo que ganha relevo no seu atual sistema de significados. A menos que aquilo que é rememorado não tenha tido nele personagem, mas apenas espectador. $\mathrm{O}$ insignificante é justamente aquele que pode rememorar por inteiro o que testemunhou, por- 
que está nessa relação de alteridade consigo mesmo na vivência circunstancial ou marginal de situações sociais que perderam o seu sentido original, porque os significados relevantes são agora outros.

\section{Transformações técnicas no processo de trabalho}

Os acontecimentos da Cerâmica São Caetano, em particular o aparecimento do demônio na seção nova de escolha de ladrilhos, sugerem a possibilidade de um reexame de certas concepções correntes nas ciências sociais a respeito do trabalho e do processo de trabalho ${ }^{9}$. Eles viabilizam um alargamento do que se sabe sobre as particularidades da alienação e do que poderia ser uma proposta de sociologia do trabalho alienado.

A aparição do demônio parece ter sido, para as várias testemunhas e protagonistas, uma ocorrência quando muito insólita, um acidente, no interior de uma fábrica moderna, dotada da mais sofisticada tecnologia do seu setor em âmbito internacional, cujo corpo de operários oscilou entre 1.500 e 2.500 trabalhadores, sem contar engenheiros, técnicos e pessoal de escritório. Com as exceções já indicadas, as pessoas que entrevistei recordam detalhadamente as circunstâncias da época, as grandes mudanças que se operaram na produção de ladrilhos com a inauguração de uma nova seção de prensagem, um novo forno e uma nova seção de escolha. A aparição do demônio, para os que dela se lembram, ficou como um incidente, superado com a perspicácia de chamar o padre da paróquia para neutralizar a sua presença com a celebração da missa e a bênção das novas instalações.

A memória dos protagonistas está centralizada nos problemas propriamente técnicos surgidos com as novas instalações e sua nova tecnologia na fase inicial da produção. Esses problemas quebraram a rotina de trabalho da Divisão de Terra Cota e definiram um ambiente de muita criatividade técnica no escritório dos engenheiros. Essa criatividade marcou fortemente as lembranças dos envolvidos.

Sociologicamente, porém, é o aparecimento do demônio que dá sentido àqueles acontecimentos. Por sua vez, a aparição não pode ser compreendida senão no quadro das circunstâncias criadas pelas inovações tecnológicas introduzidas na produção de ladrilhos naquele momento. No essencial, a questão é explicar porque a relação entre os trabalhadores e os novos meios de produção no processo de trabalho ganhou explicação, para os próprios trabalhadores, na aparição do demônio, e não numa interpretação racional das mudanças e numa reação sindical às dificuldades que elas criaram para as operárias.

Faz parte dessas circunstâncias o que ocorreu na fábrica cerca de um ano após a aparição do demônio, quando houve a grande greve de outubro de 1957. Iniciada na cidade de São Paulo, estendeu-se à região do ABC, onde a paralisação foi total. Os grevistas das outras fábricas chegaram à porta da Cerâmica, numa tarde, liderados pelo presidente do Sindicato dos Trabalhadores na Construção Civil. Tiveram que pular os portões da fábrica, que fun- 
cionava normalmente, invadindo-a e exigindo a dispensa dos operários e mensalistas, que foram forçados a sair. Os operários da Cerâmica não haviam aderido à paralisação, que assumira dimensões de greve geral e se tornou em toda a região uma greve violenta. E não o fizeram por indiferença, apesar do sindicato de sua categoria ter forte presença comunista. Os piqueteiros percorreram os fornos desligando os maçaricos de alimentação do fogo. Isso teria causado sérios danos àqueles equipamentos se após a sua saída os engenheiros e os mestres não tivessem permanecido na empresa reacendendo e regulando o fogo, nas 24 horas seguintes, evitando o resfriamento rápido dos fornos. Nesse mesmo dia a fábrica foi ocupada pela Força Pública ${ }^{10}$.

A relutância dos trabalhadores em aderir talvez se explicasse pelo fato de que a empresa tinha uma política social avançada para os padrões da época. Como se sabe, Roberto Simonsen, além de ter sido fundador da Federação das Indústrias do Estado de São Paulo, fora também fundador do SESI (Serviço Social da Indústria) e do SENAI (Serviço Nacional de Aprendizagem Industrial). Ele era motivado pelo tema da "paz social no Brasil" e por uma orientação política claramente anticomunista. Além de historiador da economia, era um teórico das relações industriais e suas idéias foram difundidas em livros e artigos ${ }^{11}$. Já no final dos anos vinte, a Cerâmica começara a conceder férias remuneradas aos seus operários. Nos anos cinqüenta, a empresa mantinha um serviço médico ainda hoje lembrado por muitos de seus trabalhadores como avançado e eficiente. $\mathrm{O} 13^{\circ}$ salário, então chamado de "abono de Natal", já era pago, antes de ser legalmente obrigatório, o que só ocorreria anos depois. Após a realização do balanço anual da empresa, parte dos lucros era distribuída a todos os mensalistas, inclusive aos menores de idade. No Dia da Criança, os menores que ali trabalhavam eram dispensados do trabalho logo após o almoço para participarem de uma festa com doces, refrigerantes, palhaços e discursos. Era uma exaltação do valor educativo do trabalho. Os menores que quisessem fazer cursos noturnos tinham as suas despesas custeadas pela empresa (cf. Simonsen, 1973) ${ }^{12}$.

No início dos mesmos anos cinqüenta, a empresa decidiu promover uma grande ampliação no seu setor de produção de ladrilhos para piso. A fama e a qualidade do produto, especialmente a resistência e a dureza, a uniformidade de cor, o brilho e a textura ampliaram a sua demanda num momento caracterizado pela expansão urbana no país ${ }^{13}$. "Grosso modo", o processo de trabalho no setor de ladrilhos estava dividido nas seguintes etapas, após a chegada aos terreiros do barro utilizado como matéria-prima, procedente de jazidas situadas longe da fábrica ${ }^{14}$ : mistura em máquinas misturadoras e secagem ao sol; moagem e peneiramento até o barro ficar reduzido a um pó muito fino, aproximadamente na consistência do talco; prensagem dos ladrilhos e seu acondicionamento em caixas de barro para serem conduzidos aos fornos; queima ou cozimento dos ladrilhos; escolha e classificação por tonalidade de cor, tamanho e espessura e encaixotamento; armazenamento e distribuição junto aos estabelecimentos comerciais e às obras. Esses diferentes momentos 
tinham seções acessórias. A preparação do barro era acompanhada por um laboratório especializado, que verificava diariamente amostras do material para determinar grau de umidade e consistência. A prensagem dos ladrilhos era diretamente dependente de uma oficina mecânica que preparava os respectivos estampos. Além disso, tinha anexo um setor de produção das caixas de barro, nas quais os ladrilhos crus eram acondicionados para serem levados aos fornos. Os fornos eram dependentes de serviços de abastecimento de lenha e óleo diesel. A seção de escolha e encaixotamento dos ladrilhos era subsidiada por uma carpintaria que produzia as caixas de madeira.

A decisão de ampliar o setor de ladrilhos, praticamente, implicou em construir uma fábrica nova. Três grandes pavilhões foram edificados para abrigar a nova seção de prensas, o novo forno túnel e a nova seção de escolha. Cada uma dessas seções, já na fábrica velha, era tecnologicamente autônoma, isto é, dependente do progresso técnico específico no respectivo setor. Para ampliação e instalação das novas seções, engenheiros percorreram a Europa e os Estados Unidos, visitaram fábricas, consultaram técnicos, reuniram informações e, finalmente, escolheram os equipamentos que seriam utilizados e $o$ modo como seria organizado o processo de trabalho.

Duas das três novas seções introduziram mudanças técnicas substantivas na produção de ladrilhos: a de prensagem e a de queima. A seção de escolha, classificação e encaixotamento não sofreu mudança em relação à seção velha, já que não houve o aparecimento de qualquer tecnologia que substituísse o caráter inteiramente artesanal do trabalho que ali se realizava. No meu modo de ver, como mostrarei adiante, nesse descompasso tecnológico está a causa fundamental das tensões que levaram ao aparecimento do demônio na nova seção de escolha de ladrilhos ${ }^{15}$.

$\mathrm{Na}$ respectiva seção velha, a prensagem dos ladrilhos era feita em prensas volantes, acionadas por um motor comum a todas elas, que por meio de um eixo comunicava o movimento às prensas através de correias. Mas, o ritmo da prensa era regulado pelo próprio prensista, que ganhava por produção. Basicamente seu trabalho consistia em controlar a subida e descida da prensa sobre os estampos através de uma alavanca segurada com a mão direita. Acionando um pedal, fazia os estampos subirem com os ladrilhos já prensados e os fazia descer para que recebessem o talco que seria prensado. Do outro lado da prensa, uma operária retirava manualmente os ladrilhos, colocava-os em caixas de barro para serem enviados aos fornos e empurrava sobre os estampos um carrinho de madeira com a matéria-prima que caía sobre eles, preenchendo a fôrma. No meio desses movimentos, o prensista, com a mão esquerda, ainda passava sobre os estampos uma estopa embebida numa combinação de produtos químicos necessários para que ficassem perfeitamente limpos. Era uma atividade intensa e sincronizada, que combinava o trabalho do prensista e da sua ajudante.

Das prensas, as caixas de ladrilhos eram levadas em carrinhos de mão, por operários, para o interior dos fornos intermitentes, circulares, nos 
quais eram acondicionados pelos forneiros especializados. Cheio o forno, a porta era fechada com material refratário e o mestre da seção acendia com lenha as bocas de fogo ao redor do forno. Quando o fogo atingia certo nível e temperatura, eram abertos os maçaricos de óleo diesel, através dos quais se regulava a temperatura no interior do forno ao longo dos dias, até que a queima se completasse. Qualquer descontrole na temperatura e na velocidade de aquecimento e desaquecimento do forno podia destruir toda a produção nele contida. A queima dos ladrilhos levava vários dias, praticamente uma semana. Aberto o forno, era ele resfriado por meio de grandes ventiladores para que os operários pudessem nele entrar e retirar as caixas com o material queimado. Elas eram, então, colocadas em suportes suspensos numa esteira aérea.

A esteira corria dos fornos para a seção de escolha anexa. Ali as caixas eram descarregadas por operários e colocadas sobre uma comprida bancada, ao longo da qual se distribuíam dezenas de operárias, as escolhedeiras. Eram quase todas muito moças, com cerca de 18 anos de idade, ou pouco mais, quase todas solteiras. Seu trabalho era muito especializado. Deviam com rapidez retirar pacotes de ladrilhos das caixas de barro e fazê-los deslizar de uma mão para outra, em diagonal, de modo que um batesse ligeiramente sobre o outro. Nesse movimento examinavam a cor de cada peça e pelo som da batida a existência de eventual defeito. $O$ trabalho das escolhedeiras exigia atenção e rapidez. Os ladrilhos defeituosos eram deixados cair numa caixa ao pé da bancada, enquanto os bons eram classificados em primeira e segunda qualidade e classificados por tamanho. Em seguida, eram empilhados sobre um carrinho que, quando cheio, era levado para as encaixotadeiras distribuídas ao redor do salão. Elas acondicionavam os ladrilhos nas respectivas caixas, enchendo os espaços entre as peças com capim seco, bem socado com uma espátula de madeira, para evitar que se quebrassem no movimento de transporte para o depósito e para o destino final. E, finalmente, pintavam sobre a caixa, com um molde, as indicações relativas às características e qualidade do material embalado.

Na nova seção de prensagem de ladrilhos, o trabalho foi muito modificado. A empresa decidiu instalar prensas Dorst, de fabricação alemã. Importou uma e as demais foram produzidas na própria fábrica, mediante licença da indústria, que enviou da Alemanha um técnico para acompanhar sua fabricação até que começassem a funcionar. A prensa Dorst era automática e bem diferente das prensas volantes da seção velha. Nestas, o próprio operário regulava o ritmo da produção numa penosa interação com a máquina. Era um trabalho pesado, como classificavam os próprios operários. Na nova seção, o operário se adaptava ao ritmo da máquina. O seu trabalho dependia de um número menor de gestos e não envolvia as complicadas contorções do corpo para fazê-la funcionar.

Do mesmo modo, as caixas com os ladrilhos crus eram transportadas para o forno através de uma esteira volante, semelhante à que levava os ladrilhos queimados dos fornos contínuos para a seção velha de escolha. Esse 
transporte já não dependia de um grande número de operários robustos que levassem o material em carrinhos de mão de um lugar a outro.

O forno contínuo era completamente diferente dos fornos intermitentes circulares. Era um forno em forma de túnel, com 40 metros de comprimento, tendo uma porta de entrada e uma porta de saída, ao longo do qual havia várias bocas de fogo, dos dois lados. Ao chegarem ao pavilhão em que se situava, as caixas de barro com os ladrilhos crus, provenientes da nova seção de prensas, eram descarregadas e arrumadas sobre vagonetas. A cada intervalo de tempo, a porta de entrada era aberta e uma vagoneta, deslizando sobre trilhos, era introduzida. Essa vagoneta corria lentamente ao longo do túnel. E ao fim de alguns dias saía pela outra porta. Desse modo, não só entrava uma vagoneta carregada de ladrilhos crus a cada intervalo de tempo, mas também, com o mesmo intervalo, saía na outra ponta uma vagoneta carregada de ladrilhos queimados. Ali, como ocorria nos fornos intermitentes, as caixas de barro eram colocadas sobre os suportes de uma esteira aérea e conduzidas à seção de escolha, separada do forno por uma parede.

Na seção de escolha, as caixas eram descarregadas sobre a bancada, como acontecia na seção velha. E daí em diante o processo de trabalho não sofrera qualquer modificação. Uma diferença, porém, se fez imediatamente presente. Na seção velha, o fluxo de ladrilhos dos fornos para a escolha era regular, mas não era contínuo. Sendo diversos os fornos, nem sempre era possível sincronizá-los. Assim como nas prensas, o ritmo de enforna e desenforna era inteiramente dependente de força humana. Não era raro que as moças da seção velha de escolha terminassem a classificação dos ladrilhos de um forno sem que os ladrilhos de outro forno começassem a chegar à bancada. Muitas vezes elas eram dispensadas do trabalho e iam para casa duas ou três horas antes do término da jornada, que começava às 7 horas da manhã e terminava às 16 horas, com intervalo para almoço das 11 até o meio-dia. Muitas delas alegavam preferência por esse trabalho porque assim conseguiam conciliar atividades domésticas com o trabalho da fábrica, embora essas dispensas não ocorressem todos os dias.

Na nova seção de escolha esses intervalos deixaram de existir. Além disso, o ritmo do trabalho foi enormemente intensificado. Embora o trabalho na nova seção de escolha não tivesse sofrido qualquer modificação em relação ao que se fazia na seção velha, passou agora a ser regulado pelo fluxo contínuo e sistemático de materiais liberados pelo forno túnel. $\mathrm{O}$ trabalho continuou sendo artesanal e dependente de qualidades pessoais das escolhedeiras e encaixotadeiras. Mas, agora inteiramente subordinado ao ritmo das máquinas e do novo forno. A máquina se fazia presente em seu trabalho de modo invisível.

\section{Ritmo e disciplina: a invisibilidade da pessoa e a visibilidade do corpo}

Até que as novas seções começassem a funcionar, desde o momento em que foi decidida a ampliação da fábrica, passaram-se alguns anos. São 
diversos os fatos que sugerem ter havido consciência, por parte da direção, nesse meio tempo, de que a nova tecnologia em implantação acarretaria modificações nas relações de trabalho. A questão do novo ritmo do processo de trabalho, agora regulado por máquinas automáticas, envolvia tanto as relações de trabalho quanto a cultura do trabalho. O problema se manifestou em duas frentes: na tentativa de impor aos trabalhadores um esquema visível de vigilância, de um lado, e na relação entre os engenheiros e os mestres (e, por extensão, os operários), de outro.

A vigilância estava de algum modo relacionada com a necessidade de difundir no interior da fábrica uma nova economia de gestos do trabalho e de promover uma redução no desperdício de tempo. É evidente que nas seções velhas, e no conjunto da fábrica, havia um sistema estabelecido de vigilância para assegurar o cumprimento da rotina de trabalho. Mas, era um sistema muito dependente da autoridade moral do mestre de cada seção e de seus auxiliares imediatos. Na seção de escolha, o amplo salão em que trabalhavam as escolhedeiras e encaixotadeiras ficava quase que sob inteiro domínio visual do mestre, que trabalhava numa cabina envidraçada colocada estrategicamente num canto. Apenas o setor de quebra de ladrilhos defeituosos e ensacamento dos cacos ficava num ângulo fora de sua visão. Mas, ali o ritmo de trabalho podia ser controlado auditivamente pelo ruído produzido, dispensando a visibilidade do que faziam as operárias.

Já na seção de prensagem isso não ocorria. A cabina em que ficavam os mestres estava situada num corredor escuro, fora do salão em que se encontravam as prensas. Mas, ali os operários ganhavam por produção e o controle das quantidades produzidas era feito pela operária que auxiliava cada prensista. As operárias dessa seção eram casadas. Lembro de ter ouvido certa vez o chefe de pessoal explicando a um engenheiro que com isso o trabalho do prensista ficava perfeitamente controlado. E que a vigilância da operária só deixava de ser eficaz se acaso se apaixonasse pelo prensista. Praticando, porém, para os costumes da época, uma grande violação moral interior. Nesse caso podia acontecer que procurasse favorecê-lo no registro de sua produção. Portanto, havia um conteúdo moral acentuado nos mecanismos de vigilância e controle, que dispensava a plena visibilidade dos corpos.

Um dos sinais de que a vigilância começava a assumir características propriamente policiais, no lugar do olhar patriarcal do chefe da seção, foi a contratação pela empresa de uma dupla de vigilantes. Eles circulavam juntos pela fábrica inteira, munidos de uma máquina fotográfica, registrando tudo que lhes parecesse irregular, para depois apresentar relatórios ao chefe da seção do pessoal. Na época, os comentários eram o de que um deles pelo menos era agente do DOPS (Delegacia de Ordem Política e Social), a polícia política. Os dois acabaram sendo demitidos, segundo se comentava na época, porque entregaram ao diretor da empresa fotografias de antigos operários e funcionários que supostamente estariam burlando o trabalho pelo simples motivo de interromperem sua atividade por uns instantes para fazer um cigarro de 
palha. Outra evidência da nova vigilância eram buracos de cerca de 5 centímetros de diâmetro abertos no centro das portas dos banheiros dos operários para que o encarregado respectivo controlasse o que os trabalhadores faziam no sanitário. A vigilância e a disciplina se deslocavam do controle pessoal e moral do mestre de cada seção para um olho vigilante (difuso e móvel) presente nos lugares mais inesperados do imenso território da fábrica ${ }^{16}$.

No meu modo de ver, a empresa, ainda que de modo vacilante, procurava implantar um padrão racional e impessoal de vigilância e disciplina. De fato, no conjunto a fábrica era muito dependente do poder pessoal dos mestres, alguns dos quais tinham poderes excepcionais. Além disso, os mestres de várias das seções estavam vinculados a uma verdadeira organização familiar e clânica no interior da fábrica. O mestre geral e o mestre da seção de ladrilhos eram irmãos, tendo havido no passado um terceiro irmão na seção de prensagem de telhas, porém já falecido na época que nos interessa. Os mestres das seções de escolha, de armazenamento e dos fornos Hoffman, onde eram queimadas as telhas, também eram irmãos entre si. Era deles meio irmão o mestre da seção de fornos de ladrilhos. O mestre da mecânica era pai do mestre da carpintaria e essa mesma família forneceu três gerações de trabalhadores à Cerâmica São Caetano. Muitos operários, operárias e empregados de escritório eram recrutados entre parentes, especialmente filhos, de trabalhadores da própria fábrica.

Especificamente do grupo dos mestres, vários apenas sabiam ler e escrever e um deles era analfabeto, sabendo apenas rabiscar o nome. Quase todos eram antigos operários da fábrica, que se tornaram mestres de suas seções como resultado de promoções decorrentes de sua experiência e conhecimento prático das respectivas funções. Havia entre eles quem tivesse 40 anos de trabalho na mesma fábrica e não eram raros os que ali estavam empregados há 30 anos.

Para se desenvolver tecnicamente, a empresa criou ao longo dos anos um corpo de engenheiros, uma boa biblioteca especializada e uma seção semi-industrial, que no seu ramo chegou a ser mais completa que a do Instituto de Pesquisas Tecnológicas. Esses engenheiros apoiavam seu trabalho na pesquisa e na experimentação. Porém, todas as suas decisões e inovações tinham que ser submetidas aos mestres antes de entrarem em execução, para que se familiarizassem com as inovações pretendidas. Embora hoje os engenheiros com quem conversei digam que não havia desencontro entre eles e os mestres, na verdade o mestre com quem falei deu abundantes indicações desse desencontro e das tensões que havia entre um grupo e outro.

Aparentemente, os mestres se sentiam ameaçados pelas inovações dos engenheiros e, no limite, ameaçados em seu emprego. Vários dos mestres acreditavam, como os artesãos das velhas corporações de ofício, que todo trabalho encerra um segredo prático. E tentavam esconder esses segredos dos engenheiros. $\mathrm{O}$ mestre da seção de prensagem sabia, por exemplo, como sabem as boas cozinheiras em relação aos ingredientes de seus pratos, que a 
qualidade do produto dependia da qualidade do barro utilizado nas prensas. Para que o barro fosse de boa qualidade era preciso que fosse "barro gordo", conforme a classificação por ele mesmo criada. Essa qualidade do barro, no seu modo de ver, não podia ser detectada no laboratório, mas apenas ao tato de mão experiente. Por isso mesmo, disse ele, houve ocasiões em que seu bom senso recomendou modificar as "receitas" de composição do barro enviadas pelos engenheiros e resumidas em fórmulas escritas nas ordens de serviço. Sem que eles disso ficassem sabendo. Mesmo quando às vésperas de sua aposentadoria um técnico do Ministério do Trabalho procurou-o para reconstituir os detalhes do processo de trabalho em sua seção, omitiu informações, como fazem as boas cozinheiras, que ensinam receitas de comidas às amigas curiosas, omitindo algum ingrediente essencial. Justamente, as informações que podem ser ensinadas na prática, mas que descritas perdem o seu conteúdo, que é o segredo.

É muito pouco provável que essa estratégia tenha sido eficiente. De qualquer modo, porém, ela é indicativa do teor de relacionamento entre o tradicionalismo personalista dos mestres e a racionalidade impessoal e técnica representada pelos engenheiros.

Da parte destes, houve claros procedimentos no sentido de superar o tradicionalismo artesanal dos mestres e de operários qualificados de tipo antigo. Alguns setores da fábrica eram muito dependentes desses artesãos, às vezes muito bem pagos por seu trabalho. Um deles não era empregado da fábrica. Era um velho canteiro, altamente especializado, periodicamente contratado para renovar o revestimento de pedra do tamborão giratório em que o manganês era reduzido a um barro fino e posteriormente a pó para produção de ladrilhos de cor preta. Uma providência dos engenheiros foi a de colocar a seu lado, "para auxiliá-lo", um hábil operário da própria fábrica para que aprendesse os segredos da profissão, de modo que a empresa deixasse de ser dependente do artesão.

A fábrica chegou a instituir um sistema de prêmios em dinheiro para os trabalhadores que sugerissem alguma inovação na produção. Lembro de um que procurou um dos engenheiros para dizer-lhe que sabia como colar as caixas de barro utilizadas para acondicionar os ladrilhos crus que eram levados ao forno e que quebravam com facilidade. Para que a empresa avaliasse se a fórmula funcionava e era econômica, o operário devia mostrar o seu segredo. O operário, porém, relutava, porque revelando-o deixava de ser segredo, que era o seu trunfo. Foi preciso que a empresa o autorizasse a levar para casa os materiais de que necessitava para fazer a mistura com a qual dizia ser possível produzir a cola e colasse em casa mesmo as caixas quebradas para serem depois testadas na fábrica. $\mathrm{O}$ experimento não funcionou. $\mathrm{O}$ mestre da seção de estampos chegou a ganhar um prêmio em dinheiro ao promover uma inovação útil e revelá-la aos engenheiros.

O ambiente dos mestres e dos, então, chamados oficiais ainda era o de uma cultura do trabalho baseada nos segredos do ofício. Era uma forma 
que mestres e operários tinham de assegurar e valorizar o próprio emprego em face da crescente despersonalização do trabalho. Não se tratava de um procedimento ingênuo. Um dos mestres, que não localizei nem pude entrevistar, fora sondado por empresa concorrente que o convidava a que para ela se transferisse com os segredos que conhecia, não só os seus, mas também os que dos engenheiros, estavam ao seu alcance. Como me narrou um seu sobrinho, tentou usar a sua possibilidade de opção para obter vantagens. Foi um fato que criou um sério mal estar na sua relação com a empresa, tendo ele sido severamente advertido a respeito das implicações morais do jogo que estava fazendo. Não teve coragem de aceitar o emprego alternativo.

Se a eficácia dessa cultura do trabalho já era pequena nas seções velhas, menor ainda se tornou com a entrada em funcionamento das novas seções, que operavam em conjunto como se fossem uma só máquina e um só corpo. Nelas, os mestres e operários requeridos deviam ser portadores de uma cultura escolar superior à dos que trabalhavam nas seções velhas, capazes de lidar com abstrações que estavam bem distantes da cultura prática dos velhos operários. Quando se preparava a instalação da nova seção de escolha, um funcionário do escritório, com curso secundário, foi convidado a se submeter a testes e a começar um treinamento com o mestre da seção velha para ser o mestre da nova seção, na tentativa de renovar o quadro intermediário com empregados que fossem mais facilmente executores das decisões técnicas produzidas pelos engenheiros.

O experiente mestre que entrevistei disse de passagem, e lamentando o que acontecera com ele próprio, que a sucessão dos mestres deveria ser feita mediante transferência de conhecimentos "a um filho, um parente, um amigo". E não a um estranho. Uma concepção claramente corporativa da relação entre o trabalhador e o saber envolvido no seu trabalho. Os engenheiros reconhecem ainda hoje que alguns mestres, como esse, tinham grande poder pessoal no interior da fábrica, controlando grande número de operários e ao mesmo tempo interpondo-se entre os engenheiros e os trabalhadores. O mesmo mestre tinha técnicos e operários de sua confiança pessoal, que chegavam ao ponto de não obedecer à ordem de um engenheiro sem consultá-lo primeiro para saber se a ordem devia ser executada ou não. Ou participando de pequenas conspirações para modificar a execução de ordens recebidas. $\mathrm{Ou}$ ainda, como ele mesmo sugeriu, agindo às ocultas para evitar que o prestígio do mestre fosse alcançado e comprometido pelas inovações dos engenheiros.

Os mestres faziam entre si críticas aos engenheiros, desdenhando o seu conhecimento "muito teórico e pouco prático". Revelavam, às vezes, falta de confiança nas ordens que recebiam quando envolviam inovações em relação ao saber tradicional. Às escondidas, e no limite, recorriam até mesmo, ainda que excepcionalmente, a um dos diretores da fábrica, que ali comparecia todos os dias, no intuito de influenciá-lo a tomar decisões diversas das que estavam sendo propostas pelos engenheiros. A eficácia dessas interferências era apenas aparente, recebidas com benevolência para não criar hostilidades 
abertas que comprometessem o ritmo regular de funcionamento da fábrica. As orientações dos engenheiros, por esses caminhos imperceptivelmente tortuosos, acabavam se sobrepondo e se impondo ao saber prático dos mestres e trabalhadores. Ao lado de uma composição de conhecimentos muito artesanais e de conhecimentos tecnicamente muito sofisticados na vida cotidiana da fábrica, havia também uma competição entre os saberes.

A suposição corrente de que a gerência científica da indústria é superior em si mesma e se impõe em decorrência dessa superioridade não é confirmada quando se observa sociologicamente o que ocorre no interior da fábrica (cf. Pereira, 1979, p.26). A Cerâmica São Caetano é um bom caso para analisar essas dificuldades. Fábrica antiga, fundada em 1913 a partir de uma velha olaria, acabou constituindo um corpo de trabalhadores muito vinculados a técnicas tradicionais de produção. Ao mesmo tempo, para acompanhar o desenvolvimento técnico do setor teve que constituir um corpo especializado de engenheiros. Formou-se, assim, no interior da empresa, uma espécie de estamento técnico oposto ao estamento dos mestres. Entre os dois a linguagem de comunicação foi a dos termos da aplicação prática das opções e decisões tomadas no plano técnico. As próprias limitações dos mestres acabaram, ao que parece, segregando o novo saber tecnológico e a nova racionalidade que ele encerrava, no âmbito do grupo de engenheiros. De modo que os trabalhadores ocupados nos diferentes momentos do processo de trabalho, inclusive os mestres, nem sempre tinham uma clara compreensão de tudo que estava envolvido no que faziam.

A diversidade das relações sociais e das mentalidades no interior da grande indústria sugere que se leve em conta, nos estudos sociológicos, a diversidade das condutas de classe num mesmo estabelecimento industrial. $\mathrm{O}$ desenvolvimento desigual da tecnologia e das técnicas de produção implica no desenvolvimento desigual da própria concepção de classe social e na desigual conduta de classe em relação ao capital e à empresa. Na mesma época das ocorrências aqui examinadas, os ferramenteiros da oficina mecânica, uma verdadeira fábrica de máquinas e equipamentos, que se dedicava principalmente à fabricação das novas prensas Dorst, promoveram uma solitária paralisação de sua seção, cruzando os braços diante dos respectivos tornos para obter uma melhora salarial. Não foram acompanhados pelos operários e pelas operárias das outras seções, a cujo trabalho, aliás, sua greve não afetava. Aquela seção era como uma fábrica no interior da fábrica ${ }^{17}$.

Além disso, a falta de uniformidade tecnológica no processo de produção enfraquece o poder e o domínio da gerência científica e abre espaço para a interferência de outros saberes, historicamente atrasados em relação ao desenvolvimento dos setores de ponta de uma fábrica. Ao mesmo tempo, é preciso ter em conta que, associada a essa interferência de arcaísmos vários, há uma organização social da produção mediatizada por esses saberes, como era o caso do parentesco entre os mestres e do esquema de lealdades pessoais por eles instituído. Mesmo quando se pensa na administração das relações 
humanas e nos grupos informais no interior da fábrica, em contraposição à gerência científica, é preciso ter em conta que nem sempre tais grupos assumem a racionalidade da produção tal como é estabelecida pelo setor mais desenvolvido.

No caso da Cerâmica, valores e concepções patriarcais interferiam diariamente no confronto com a racionalidade do saber tecnológico veiculado pelos engenheiros. A maioria dos operários e mestres morava em dois bairros que se desenvolveram ao lado da fábrica. Com isso havia uma teia de relações sociais de vizinhança exterior à fábrica que não deixava de se fazer presente, de algum modo, no seu interior ${ }^{18}$. Boa parte do modo como a questão da aparição do demônio foi interpretada teve a ver com essa cultura de vizinhança, que estava inteiramente fora do alcance da cultura técnica confinada ao interior da indústria.

\section{0 demônio no lado oculto do trabalho}

A minha suposição é a de que a aparição do demônio na seção de escolha da Cerâmica São Caetano, em 1956, explica-se pelas circunstâncias da transição que a fábrica estava sofrendo naquele período. Para os engenheiros e para a direção da empresa a adoção de critérios impessoais no relacionamento entre eles, os mestres e os operários era uma decorrência natural da modernização da empresa e uma necessidade derivada do novo e conseqüente padrão de racionalização do trabalho. As evidências que colhi, porém, e minha própria observação na época, indicam que do lado dos mestres essas mudanças foram recebidas com preocupação e resistência. A aparição do demônio onde supostamente não houve qualquer mudança no processo de trabalho, a seção de escolha, foi expressão dos temores gerados pelo conservadorismo desses setores colocados à margem das inovações e/ou das decisões que levaram a elas. Foi a forma que o imaginário das operárias deu às inovações para compreendê-las no conflito que encerravam.

O novo modo de produzir os ladrilhos ficava muito longe do modo de produzir em que o saber prático dos mestres ainda era essencial. Mas, suas limitações ficavam evidentes na seção de escolha, onde justamente não fora possível introduzir nenhuma inovação técnica. De fato, o processo de trabalho na Cerâmica se desenrolava ao longo de uma sequiência de procedimentos que combinava diversas e desiguais etapas da história do desenvolvimento capitalista, como mostrei. Esse foi outro fator responsável pelo aparecimento do demônio naquele lugar.

Essa diversidade de relações com o objeto de trabalho parece sugerir que ao longo do processo e nas diferentes seções havia diferentes modalidades do que Marx chama de sujeição do trabalho ao capital (e poderíamos falar, também, em diferentes graus dessa sujeição). Mas, penso que é possível mostrar que ao invés de diferentes modalidades de sujeição, estamos em face de diferentes formas sociais da sujeição especificamente capitalista do trabalho ao capital. Como é sabido, Marx distingue entre sujeição real e sujeição 
formal do trabalho ao capital (Marx, 1971, p. 54 ss.). Na sujeição formal, o artesão mantém os procedimentos artesanais e o saber que os sustentam. $\mathrm{O}$ capital compra a sua força de trabalho para se apossar do produto, sem se apossar, no entanto, do modo de fazer as coisas, isto é, do processo de trabalho. Seu domínio se limita, em princípio, ao processo de valorização, pois o que compra, nesse caso, é, antes de tudo, tempo de trabalho e não modo de trabalhar. A dominação do capital sobre o trabalho aparenta ser uma dominação externa (Marx, 1981, p.402). A alienação do trabalhador se dá estritamente em termos da alienação do seu trabalho. Mas, não alienação de sua consciência profissional, que permaneceria, assim, um contraponto crítico ao processo de trabalho capitalista ${ }^{19}$.

As interpretações de Marshall (1967) e Thompson (1979) sobre a importância das tradições pré-capitalistas na resistência aos efeitos expropriatórios da expansão capitalista e na afirmação dos direitos sociais dos trabalhadores ganham sentido, no meu modo de ver, nessa desvinculação transitória entre a consciência e o trabalho. Desvinculação que não existe quando se instaura a sujeição real do trabalho ao capital, quando o capital desmonta o processo de trabalho organizado segundo a concepção artesanal, fragmenta seus procedimentos e o refaz segundo sua própria lógica. Isto é, reorganiza-o com base num saber que lhe pertence e que não pode ser apropriado isoladamente e com sentido por nenhum trabalhador em particular. É desse modo que se organiza o modo especificamente capitalista de produção.

O caso da Cerâmica sugere, porém, que algumas minúcias se escondem por trás dessas formulações quando o processo de trabalho é analisado mais de perto, nas microrelações que o compõem. E quando surge a oportunidade de examiná-lo pelo avesso e pelo seu lado invisível, como nesta anomalia que foi a aparição do demônio. Ali, o momento artesanal do processo de trabalho foi criado pela própria grande indústria, na falta de recursos técnicos que compatibilizassem o trabalho de escolha e classificação dos ladrilhos com os outros momentos do processo de trabalho. O desenvolvimento tecnológico do ramo de produção de ladrilhos foi desigual, como indiquei antes. A própria história da fábrica permitia constatá-lo.

É preciso, pois, distinguir entre artesanato tradicional e artesanato industrial. Este último é o artesanato que surge em consequiência das próprias necessidades e dificuldades do processo de trabalho na grande indústria, integrado e comandado pelos setores tecnologicamente mais modernos e desenvolvidos. Nesse caso, só aparentemente o trabalhador transforma o seu corpo em mediador do processo, seu próprio ritmo determinando o ritmo do processo de produção. Nos setores automatizados, a máquina é claramente a mediadora do ritmo do corpo. No caso da seção de escolha, embora não tivesse ocorrido a introdução de nenhum equipamento que acarretasse inovações no uso do corpo, nos gestos e movimentos, a coerção da máquina chegou através do novo ritmo do trabalho comandado pelas prensas automáticas, no início do processo, e pelo fluxo contínuo de ladrilhos saindo do forno túnel ${ }^{20}$. 
Ao conjunto das operárias a unidade diversificada do processo de trabalho impôs o ritmo da máquina invisível, quando o ritmo das novas prensas e do novo forno dominou todo o processo de trabalho. Embora não fluísse de equipamentos imediatamente visíveis para as próprias operárias. (Situação inversa da que ocorre nas usinas de açúcar: a primeira etapa do processo de trabalho é agrícola, de modernização incompleta. A etapa industrial, moderna, se coloca depois da etapa atrasada. No caso da Cerâmica, a etapa atrasada se punha depois da etapa moderna) $)^{21}$.

Essa captura invisível do trabalho artesanal pela racionalidade da grande indústria fez das concepções patriarcais dos mestres a respeito da autonomia dos ofícios e da relevância do saber prático e seus segredos uma simples ilusão. Esse mundo impregnado de idéias, procedimentos e valores pré-capitalistas estava de fato acabando. As mudanças que estavam ocorrendo na Cerâmica São Caetano nos anos cinquienta implantavam uma nova divisão do trabalho social, que separava o trabalho intelectual do trabalho manual. Apesar da notória e delicada prudência da direção da empresa e de seus engenheiros, que conviveram com os mestres e suas concepções por longo tempo ainda, sem jamais ter negado legitimidade ao saber tradicional, na prática era um saber que tinha utilidade transitória. No padrão que começou a disseminar-se com as novas seções, o monopólio do conhecimento técnico pelos engenheiros deixava aos mestres a função de supervisores na aplicação desse saber "externo" à relação do trabalhador com seu trabalho. Ao operário já não cabia pensar o seu trabalho, mas apenas reagir interpretativamente aos movimentos que o ritmo do processo de trabalho impunha ao seu corpo. $\mathrm{O}$ processo de trabalho não dependia da mediação de sua interpretação para que tivesse sequiência. Seu corpo fora transformado num instrumento dos movimentos automáticos da linha de produção.

Para as operárias da seção de escolha, essa captura teve peculiaridades. Ela se deu no plano do ritmo do trabalho. Mas não se deu no trabalho propriamente dito. Daí a aparência de mera sujeição formal do trabalho ao capital. Esse trabalho ainda dependia de habilidades estritamente artesanais e, portanto, de um conhecimento que era próprio do artesão. Mas, o ritmo do trabalho já não era regulado pela disposição do corpo. Era regulado pelos próprios equipamentos que nas seções anteriores adquiriam a velocidade ditada por suas possibilidades técnicas. Os dois engenheiros reconheceram que o ritmo do trabalho se intensificou e um deles lembra-se bem que naqueles dias era grande a tensão na seção de escolha em consequiência das dificuldades que as operárias estavam tendo para fazer a escolha e a classificação de todo o ladrilho que lhes chegava à mesa. Foi preciso que o desenfornador intercalasse a colocação das caixas de ladrilhos saídas do forno, de modo a deixar um suporte vazio entre dois, diminuindo assim a remessa de materiais para as escolhedeiras.

Mas, não foi esse imediatamente o fator que desencadeou a visão do demônio, embora tenha sido, muito provavelmente, a sua causa mais im- 
portante. Os primeiros ladrilhos que saíram do novo forno túnel nos primeiros dias após o início do seu funcionamento eram em altíssima proporção defeituosos, tortos e geralmente rachados. $\mathrm{Na}$ produção dos velhos fornos intermitentes, mais de $90 \%$ dos ladrilhos eram de primeira qualidade. A movimentação de mestres e engenheiros entre o pavilhão do forno, a nova seção de escolha e o escritório dos engenheiros foi tensa, intensa e visível naqueles dias. O que não deixou de ser percebido pelos próprios trabalhadores, especialmente pelas operárias da escolha, em cuja seção estava o destino final do que saía do forno. Aquilo que para os engenheiros não era um erro, mas apenas rotina de ajustamento dos novos equipamentos ao seu funcionamento normal, para as operárias em especial pareceu algo fora de controle, como se pode inferir do que ocorreu depois.

Por essa mesma época, o engenheiro que dirigia a Divisão de Terra Cota estava propondo e desenvolvendo experiências no sentido de reduzir a espessura dos ladrilhos a cerca de metade da espessura normal. Se a experiência desse certo, como deu, seria possível produzir o dobro de área de piso praticamente com a mesma quantidade de matéria-prima da produção antiga, com o dobro da capacidade de enforna, maior rapidez na queima do produto, mais agilidade na escolha. Mas, também aí houve inicialmente problemas e um claro confronto entre mestres e engenheiros, tanto pela questão da qualidade apropriada de barro para o novo tipo de ladrilho quanto pela questão de uma surpreendente falta de brilho no novo produto. $\mathrm{O}$ brilho era uma característica tradicional da marca dos ladrilhos "São Caetano". Mas, nas novas prensas, o ladrilho saía fosco. Descobriu-se, depois, acidentalmente, graças às observações de um operário qualificado, de confiança do mestre da seção, que se os estampos de aço fossem substituídos por estampos de bronze o brilho também apareceria nos ladrilhos finos. Além disso, houve problemas no assentamento das novas peças, pois os pedreiros utilizavam a técnica de assentamento do ladrilho mais grosso. O simples desenvolvimento de uma técnica ajustada às novas características do produto resolveu o problema.

Portanto, as grandes transformações que estavam ocorrendo na produção traziam para o cotidiano da fábrica tensões e incertezas, do ponto de vista dos trabalhadores e mesmo dos mestres, que não podiam fazer parte de uma rotina de trabalho legitimada pela tradição. Justamente, o risco e a experimentação eram novos componentes rotineiros da produção fabril moderna que não foram assimilados rapidamente pelos operários e pelos mestres.

Antes mesmo que um dos engenheiros descobrisse a causa dos defeitos nos ladrilhos saídos do novo forno túnel, ocorreu a aparição do demônio na seção de escolha. O problema todo estava no fato de que os maçaricos que alimentavam as bocas de fogo, com óleo diesel, às vezes entupiam, diminuindo o jato de combustível. Com isso, a temperatura se tornava desigual em bocas paralelas, situadas na mesma longitude ao longo do túnel, o que produzia queima desigual dos ladrilhos, provocando as rachaduras.

As operárias da seção de escolha interpretaram a seu modo os desa- 
justes da produção e o aparecimento de grandes quantidades de ladrilhos defeituosos. Elas os atribuíram à presença do demônio na fábrica e por isso se sentiam pessoalmente ameaçadas. Ele era visto meio sorridente, bem vestido, como os engenheiros, num canto da seção. As operárias alegavam, também, que nos momentos em que ele aparecia, sentiam cheiro de enxofre, um cheiro que a cultura popular associa à figura de satanás. A contramestre da seção era uma senhora muito católica, moradora no bairro vizinho à fábrica em que também moravam as operárias. E muito católico era o próprio mestre da seção de escolha, cujo irmão, também mestre de outra seção, era o organista da matriz da Sagrada Família, em São Caetano. Aparentemente, foi na conversa deles com as operárias que surgiu a idéia de chamar o padre da paróquia de Vila São José para celebrar uma missa e benzer as novas instalações da fábrica. Alegavam as operárias que o demônio estava ali presente porque a fábrica começara a funcionar antes de receber a bênção do padre.

A concepção subjacente ao comportamento delas nos diz que a riqueza é pagã e, por isso, em si mesma é má. É nela que o mal ganha corpo. Nesse sentido, ela é negação da humanidade do homem que a produz, que na produção se descobre em antagonismo com sua obra, sua obra rebelada contra ele, contraposta e oposta a ele, fazendo-o instrumento dela. É o rito da bênção dos locais, meios e condições da produção que reconcilia simbolicamente o trabalhador com seu produto. Legitimando, porém, o antagonismo que os confronta ${ }^{22}$. De fato, celebrada a missa e benzidas as instalações, com a presença dos proprietários, dos engenheiros, mestres e de todos os operários, inclusive os das velhas seções das duas divisões da fábrica, o demônio não se fez mais visível. Nesse meio tempo, foi descoberta a causa dos defeitos nos ladrilhos, que passaram a ser produzidos com a qualidade tradicional.

Sociologicamente, o demônio deu visibilidade ao invisível das inovações tecnológicas que alteraram o ritmo do trabalho e por esse meio oculto se apossaram do corpo das operárias. Numa passagem justamente célebre, Marx diz que a produção do pior artesão é superior à produção da melhor abelha porque $\mathrm{o}$ artesão pensa sobre aquilo que faz ${ }^{23}$. $\mathrm{O}$ trabalho não se materializa senão pela interpretação que dele faz o próprio trabalhador. Numa situação, porém, de trabalho alienado e de separação entre o trabalho intelectual e o trabalho manual, qual o lugar do pensamento do trabalhador na produção? Mesmo mantendo a forma artesanal da produção, no caso das operárias da seção de escolha, o trabalho foi capturado de modo invisível pelos meios de produção mais modernos do conjunto do processo de trabalho. O lugar vazio do pensamento que dirige o trabalho e se manifesta no produto que dele resulta foi nesse caso ocupado pelo imaginário e pela fabulação. Mas, um imaginário fundado na memória coletiva, cujos componentes, conservados inconscientemente, emergiram do fundo dos tempos que ela encerra e guarda. Prontos, no entanto, para dar uma coerência arcaica a um presente contraditório e sem sentido, porque nele a significação foi separada do vivido ${ }^{24}$.

A grande maioria dos operários da Cerâmica era constituída de 
migrantes da zona rural que chegaram ao subúrbio com a crise do café nos anos trinta, quando a cidade de São Paulo viveu um importante surto industrial. Nos próprios anos cinquienta, houve um grande fluxo de migrantes rurais do Nordeste do país e de Minas Gerais rumo ao subúrbio. Nos trabalhos pesados das prensas e dos fornos era notória a presença de nordestinos. As moças das seções velha e nova de escolha de ladrilhos eram na maioria filhas desses migrantes, cuja vida nos chamados Bairro da Cerâmica e Vila São José, ao lado da fábrica, estava impregnada de valores católicos tradicionais e rurais ${ }^{25}$.

Não surpreende, portanto, que um ingrediente desse imaginário, o demônio, emergisse no esvaziamento cultural promovido pelas transformações técnicas que a fábrica levara ao seu trabalho. Nesse sentido, foi alienada manifestação de resistência. Resistência a que e em nome de que? Há que considerar aí dois planos. De um lado, o do entendimento imediato que das mudanças podiam ter os trabalhadores, em particular as operárias da seção de escolha, na situação técnica e social em que trabalhavam. Mas, de outro, também, os acontecimentos, as pequenas conspirações e os pequenos boicotes cotidianos, sobretudo a aparição do demônio, sugerem uma resistência implícita além do imediato e do imediatamente perceptível: uma crítica na própria ação, como a denomina Lefebvre $(1958, \text { p.18 })^{26}$, às transformações técnicas e sociais pelas quais a fábrica estava passando.

O circunstancial e conjuntural da crise provocada pelas transformações técnicas aqui mencionadas, agravadas pelo descompasso técnico no interior do processo de trabalho, como ocorreu na seção de escolha, prevaleceu sobre o caráter de classe subjacente ao conflito implícito naquelas ocorrências. Caráter de classe que não emergiu nem à consciência das trabalhadoras nem à consciência dos patrões. No meu modo de ver, o núcleo da resistência expressada pelas tensões surgidas com a aparição do demônio ganha sentido na cobrança das operárias à empresa para que providenciasse o benzimento das novas instalações. Portanto, para que celebrasse as primícias da nova produção, como era próprio das culturas agrárias ${ }^{27}$. Essa cobrança significou de fato a exigência da restituição simbólica da fábrica ao tempo cósmico e qualitativo que fora banido com a completa sujeição de todo o processo de trabalho ao tempo linear, quantitativo e repetitivo da produção automatizada, na imposição dos gestos do trabalho parcelar. Uma banalização do trabalho artesanal, mas também banalização da pessoa da trabalhadora.

A celebração da missa e o benzimento da fábrica implicou no estabelecimento da festa como ponto de referência crítico à linearidade do tempo de trabalho que agora se implantava completamente. A restituição do sentido da festa como contraponto do trabalho foi também uma forma de restabelecer o nexo entre o cotidiano da produção linearizada e o não-cotidiano da celebração e das grandes concepções da vida e do homem, ameaçadas, na interpretação das operárias, pelas inovações técnicas e sociais implantadas ${ }^{28}$. Vinculado, em nossa cultura ocidental, às grandes concepções míticas e arquetípicas do humano, na negação da humanidade do homem, o demônio apareceu 
naturalmente como a figuração da ameaça à essa humanidade pela racionalização do trabalho, como denúncia do domínio da pessoa pela coisa presente e invisível.

É também significativo que essa crítica mediatizada pelo imaginário arcaico tenha ganho visibilidade na figura do demônio que vê, mas não fala nem se move. E se deixa ver, vendo, por alguns e não por outros. Justamente, ver e vigiar foram técnicas de controle social tentadas simultaneamente com as inovações aludidas. Mais do que qualquer outra coisa, a aparição do demônio foi uma figuração crítica do ver oculto, da vigilância dissimulada e desleal, porque punha em dúvida os mecanismos patriarcais da lealdade pessoal que até então haviam assegurado a ordem interna na fábrica. Nas relações, agora, o ingrediente da suspeita e da dissimulação $0^{29}$. Justamente, relações sociais assim baseadas implicam em trazer para o primeiro plano do relacionamento a mediação do conhecimento que constrói a relação, isto é, implicam no predomínio do imaginário, o simbólico como condição do vínculo social, a precedência do cotidiano em relação ao não-cotidiano ${ }^{30}$.

O que surpreende é a eficácia desse tradicionalismo rural invadindo a grande indústria e a produção moderna e nelas se recriando e se atualizando. A aparição do demônio tem sido até os dias de hoje freqüentemente mencionada em estudos sociológicos e antropológicos na América Latina ${ }^{31}$. Inicialmente o demônio esteve associado ao ouro, o que claramente nos remete ao imaginário medieval e às concepções difundidas pelos missionários na época da Conquista. Depois foi associado ao dinheiro e eu mesmo encontrei imaginosas associações desse tipo entre camponeses da Amazônia no recente período de expansão capitalista naquela região. Na cultura popular do Nordeste do Brasil tal como é apreendida pela chamada literatura de cordel, o inferno é concebido como um depósito de mercadorias. O caso da aparição do demônio na Cerâmica revela que ele foi também associado aos meios capitalistas de produção, máquinas e instalações. À medida em que a riqueza muda de forma, a expressão do mal, que é satanás, também migra de uma forma a outra.

Nele as contradições da riqueza, enquanto fruto do trabalho e instrumento de opressão do trabalhador, assumem uma figuração humana, no falso humano que é o demônio, na sua capacidade de assumir forma humana sem humano ser. Por meio dele, o invisível, que é a força impessoal do processo de trabalho capitalista, se torna visível. É por meio da figuração do poder do mal que essa força se permite ver e conhecer ${ }^{32}$. $\mathrm{O}$ caso da Cerâmica indica que na cultura operária, de uma certa fase ao menos e na circunstância da coexistência de tempos distintos da história do trabalho, pelo atalho da aparição que revela a força do mal, o trabalhador toma consciência do duplo e contraditório caráter do trabalho: concreto e abstrato ${ }^{33}$. Também toma consciência da força objetiva do trabalho social que se tornou uma força do capital. E da permanente coexistência dos opostos na produção, o que se vê e o que não se vê, mas é e está lá.

Recebido para publicação em abril/1994 
MARTINS, José de Souza. The apparition of the devil in the factory, in the middle of production. Tempo Social; Rev. Sociol. USP, 5(1-2): 1-29, 1993 (edited in nov. 1994).

ABSTRACT: In 1956, several apparitions of the devil during a whole week in a large modern factory in the outskirts of São Paulo showed that the phenomena of demonization can also take place outside the traditional and rural world of the peasantry. Modern industrial workers are also liable to invoke archaic imagery in an effort to understand changes in production technology. When industrial modernization introduces a radical divide between thinking and doing in the work process, archaic imagery can fill the vacuun to give it meaning: the meaning that its irrationality can bring.

\section{Notas}

${ }^{1}$ Sou imensamente agradecido pela disponibilidade e pela atenção com que fui recebido pelos Drs. Renato Martins de Siqueira e Airton Mitidiéri e pelos Srs. Renato Maresti e José Francisco Martins, antigos funcionários da Cerâmica São Caetano S.A. Eles generosamente se dispuseram a ouvir as minhas perguntas e a respondê-las com esclarecimentos detalhados sobre as ocorrências relacionadas com o caso aqui estudado. Deram-me, também, o prazer de revê-los trinta e três anos após a minha saída da fábrica. Agradeço, igualmente, ao padre Carlo Fabbrini a acolhida atenciosa no bucólico recanto de São Bernardo do Campo em que exerce hoje o seu ministério. É inteiramente minha a responsabilidade pela interpretação aqui contida dos acontecimentos de 1956.

${ }^{2}$ Trabalhei na Cerâmica São Caetano S.A. de novembro de 1953 a fevereiro de 1958, dos 15 aos 19 anos de idade.

${ }^{3}$ Um dos engenheiros que entrevistei mencionou que as operárias que desmaiavam se diziam possuídas pelo demônio. Minha própria lembrança, porém, é a que tomei em consideração neste estudo: a de que as moças viam o demônio. Até porque as referências que tive na época vinham acompanhadas de uma descrição da fisionomia da aparição. Isto é, satanás era um ente com quem as operárias que o viam estavam numa relação de alteridade e de exterioridade. Não seria assim se estivessem possuídas. O padre Carlo Fabbrini me confirmou essa observação. Se fosse possessão, ele teria sido chamado para exorcizar o demônio. E num caso como aquele, envolvendo um grande número de pessoas, essa providência teria dependido de uma autorização especial do bispo diocesano e de um rito especial. Se tal tivesse ocorrido, pela sua excepcionalidade, ele teria guardado viva memória da ocorrência, o que afinal não se deu. Além disso, a possessão se expressaria no comportamento anormal da possuída e não na passividade do desmaio. Um ano antes da aparição do demônio na fábrica, houve a aparição do demônio no bairro do Catulé, município de Malacacheta, Minas Gerais. Ali, sim, vários moradores foram possuídos pelo demônio. No estado de possessão, mataram animais e crianças (cf. Castaldi, 1957).

${ }^{4}$ Utilizo a concepção de acontecimento analisador-revelador no sentido que lhe dá Lefebvre analisando crises de outras dimensões: "Se é sempre conveniente analisar a crise (...) é preciso igualmente considerar essa mesma crise como analisador do mundo atual. Esta modificação metodológica transforma o horizonte e o curso do pensamento" (cf. Lefebvre, 1978, p.232-233) (grifos do original). Em livro anterior, o mesmo autor assinala que "as transgressões servem de analisadores-reveladores; este processo, por efeito das transgressões, aparece na sua totalidade contraditória, dialética" (cf. Lefebvre, 1973, p. 16). Cf., também, Norbert Guterman e Henri Lefebvre (1979, p.3).

${ }^{5}$ Fiz tentativas infrutíferas de localizar, nos bairros vizinhos à fábrica, antigas operárias que tivessem testemunhado as consequiências do aparecimento do demônio. Esses bairros sofreram muitas transformações desde aquela época, afetados pelas migrações que têm marcado a região industrial do ABC. Isso talvez explique essa dificuldade. Além disso, as operárias da seção de escolha de ladrilhos eram mulheres jovens e solteiras, mais sujeitas a mudança de local de moradia em conseqüência do casamento. 
${ }^{6}$ A Cerâmica São Caetano S.A. tinha nessa época uma Divisão de Terra Cota e uma Divisão de Refratários. A Divisão de Terra Cota abrangia dois grandes setores: um de produção de telhas coloniais, lajotas e tijolos brilhantes com barro granulado e "úmido" e outro de produção de ladrilhos com barro pulverizado e "seco". A Divisão de Refratários produzia tijolos e peças especiais para altos-fornos, especialmente os da Cia. Siderúrgica Nacional, de Volta Redonda (RJ). Fora inaugurada, em 1944, pelo presidente Getúlio Vargas. A empresa pertencia à família de Roberto Simonsen, já falecido na época dos fatos aqui analisados.

${ }^{7}$ Vários dos adolescentes eram invisíveis para os esquemas de vigilância da fábrica. Mas, eram invisíveis, também, para os operários e o próprio sindicato. Na greve de outubro de 1957 (v. adiante), as atividades da fábrica foram interrompidas à força e os operários foram obrigados a sair. Vários adolescentes, porém, nem sequer foram notados e permaneceram lá dentro, atônitos, sem saber o que fazer. Eu mesmo saí para comprar algumas coisas para os engenheiros que iam ficar na fábrica e voltei a entrar, passando pelo piquete, sem ao menos ser interpelado. Só depois é que deixei a fábrica definitivamente. No fundo, tanto para os patrões como para o sindicato, os menores que ali trabalhavam viviam numa espécie de limbo das relações de classe. Uma única vez, depois de estar trabalhando ali há muito tempo, alguém se deu conta de que, pelo meu trabalho, eu podia ver mais do que outros. Fui, então, advertido mais ou menos da seguinte maneira: "Tudo o que você vê aqui não pode ser contado a ninguém. Um dia você se casará e terá filhos. Nem a eles deverá contar o que viu aqui." A preocupação, era evidentemente, não só com o que eu podia ver no funcionamento da fábrica, mas principalmente com o que eu podia ler nos documentos que levava de um lado para outro. A sábia preocupação era, obviamente, com o discernimento a posteriori que eu poderia ter a respeito do que via e lia, isto é, das informações e dos segredos técnicos da produção.

${ }^{8}$ Sobre a relação entre a memória individual e a autobiografia, de um lado, e a memória coletiva, de outro, cf. Maurice Halbwachs (1990, p.51).

${ }^{9} \mathrm{Na}$ análise do processo de produção, enquanto unidade desencontrada do processo de trabalho e do processo de valorização, Marx já está propondo, de fato, o que se poderia chamar hoje de estudo sociológico dos aspectos propriamente cotidianos das relações de produção. As sugestões indiretas de uma análise desse tipo, contidas na noção marxiana de processo de trabalho, são incorporadas por Vera Maria Candido Pereira, na perspectiva fenomenológica, quando destaca, na apresentação de seu livro, a intenção de estudar não só as características do processo de trabalho, mas, também, "a maneira como os trabalhadores o experimentam". O que, de alguma forma, conflita com a orientação althusseriana de seu estudo (cf. Pereira, 1979, p.19).

${ }^{10}$ Sobre a repercussão da greve de 1957 na região do ABC, cf. Fábio Antônio Munhoz (s/d, p.12) e Aloizio Mercadante (org.) (1987, p.91).

${ }^{11}$ Muitas referências à Cerâmica São Caetano podem ser encontradas no excelente livro de John D. French (1992).

${ }^{12}$ Foi a Cerâmica São Caetano que pagou o meu curso secundário no Instituto de Ensino de São Caetano do Sul. E era um funcionário da empresa que examinava e comentava minhas notas e minha carreira escolar.

${ }^{13}$ A linha principal de produção de ladrilhos era a dos sextavados e retangulares vermelhos. Mas, eram produzidos também ladrilhos amarelos, pretos e pérolas. Também eram produzidas lajotas com a mesma técnica de produção dos ladrilhos. As peças quebradas ou com defeitos eram transformadas em cacos para pisos. A dureza dos ladrilhos era reconhecida e resistia ao risco de uma lâmina de aço, sem que ficassem marcas. A fábrica tinha como lema: "Para riscar um ladrilho São Caetano, só outro ladrilho São Caetano".

${ }^{14}$ As jazidas de matérias-primas utilizadas tanto na Divisão de Terra Cota quanto na Divisão de Refratários estavam localizadas em vários pontos do país, algumas delas na Bahia. Eram geridas por uma subsidiária da Cerâmica, a Cia. Paulista de Mineração - COPAMI.

${ }^{15}$ A desigualdade do desenvolvimento tecnológico entre as etapas do processo de trabalho, tanto na indústria quanto na agricultura, é hoje conhecimento de senso comum na sociologia do trabalho. Sobre a indústria, cf. Vera Maria Candido Pereira (1979, p.24). Lefebvre já havia observado "que a desigualdade de desenvolvimento se estende e se estenderá não somente ao país, mas às regiões, aos ramos da indústria e mesmo ao interior das empresas (justaposição de técnicas atrasadas e de técnicas modernas)" (Lefebvre, 1957, p.248). 

1993 (editado em nov. 1994).

${ }^{16}$ Raríssimas informações que vazavam acidentalmente das reuniões semanais das sextas-feiras à tarde entre o diretor da empresa e os engenheiros indicam que era forte o temor do comunismo entre os proprietários da fábrica. Isso talvez explique porque um dos dois vigilantes era, provavelmente, como se dizia na época, agente da polícia política. A vigilância que procurava estabelecer a plena visualização dos corpos dos trabalhadores difundia um método de disciplina do trabalho baseado na visibilidade difusa e impessoal do que se fazia na fábrica, diferente do método da coação moral e indireta dos mestres das seções. Revelava, também, uma clara consciência da relação entre corpo e poder. Um rapaz espionado pelo encarregado de um dos sanitários masculinos, através de orifício feito exatamente para isso na porta de cada banheiro, foi suspenso do serviço porque fora surpreendido se masturbando. É compreensível que o olho do poder, na fábrica, tenha sido um "olho móvel". Com umas poucas exceções, estavam as seções instaladas segundo a concepção do panóptico, de que nos fala Foucault. Num lugar estratégico ficava, em plano mais elevado, um pequeno escritório envidraçado onde trabalhavam o mestre e seus auxiliares. Porém, havia muitos recantos pela fábrica fora de qualquer visibilidade "natural". Sobre esses temas, cf. Michel Foucault (1975) e (1982).

${ }^{17}$ Fábricas fundadas entre o fim do século XIX e o início do século XX, como a Cerâmica São Caetano, tinham usualmente uma oficina mecânica destinada ao conserto, manutenção e recondicionamento de máquinas, geralmente importadas e de manutenção difícil e incerta por parte dos fabricantes. Como na Cerâmica, algumas dessas oficinas estavam em condições de produzir equipamentos industriais substitutivos dos importados. Foram essas oficinas, em grande parte, que asseguraram a sobrevida das indústrias brasileiras durante as duas guerras mundiais. Algumas delas se transformaram em fábricas autônomas. A indústria de bens de capital já estava instalada no interior da indústria de bens de consumo quando foi chamada a substituir importações com as dificuldades das guerras. Ela não nasceu, como pensam alguns historiadores da economia, dos estímulos de mercado criados artificialmente por esses bloqueios. Além disso, já havia uma incipiente indústria de equipamentos no país desde o final do século passado. Lembro que na Revolução de 1932 essas indústrias foram adaptadas em questão de dias para produzir material bélico.

${ }^{18} \mathrm{O}$ tema das repercussões do modo de vida da comunidade vizinha no interior da fábrica já aparece em pioneiros manuais de sociologia industrial. Cf. Eugene V. Schneider (1957, esp. p.365). No Brasil, o tema foi originalmente estudado por Juarez Rubens Brandão Lopes, quase na mesma época das ocorrências aqui analisadas. Na concepção, porém, de que a comunidade envolvente estaria numa relação de contraponto com a indústria portadora do racional e do moderno, como fonte de condutas tradicionalistas. Ver Lopes (1964) e (1967). Mais recentemente, José Sergio Leite Lopes retomou o tema, examinando o que de fato é um conflito entre a vila operária e a fábrica (Cf. Lopes, 1988).

${ }^{19}$ Não obstante, "a realidade humana da produção pode entrar em contradição com seu resultado 'inumano'; como a atividade e a maneira de produzir podem entrar em contradição com o que produzem..." (cf. Gorz, 1964, p.55) (grifos do original).

20 “A redução do trabalhador ao nível de um instrumento no processo produtivo não está, de modo algum, exclusivamente associada com a maquinaria. Devemos também observar, ou na ausência de maquinaria ou em conjunção com máquinas operadas individualmente, a tentativa de tratar os próprios trabalhadores como máquinas. Este aspecto da gerência científica foi ampliado pelos sucessores imediatos de Taylor" (cf. Braverman, 1981, p.151) (grifos do original). Roberto Simonsen, patriarca da família de proprietários da Cerâmica, foi defensor dos princípios tayloristas e sobre o assunto fez discursos e conferências (cf. Simonsen, 1973, esp. p.436-442).

${ }^{21}$ Um estudo comparativo de processos de trabalho em que setores arcaicos estão localizados em momentos opostos, no começo ou no fim, poderia esclarecer minúcias do processo de produção capitalista e das relações de classe que têm mais importância do que se pode supor. Para isso, é necessário que os sociólogos do trabalho não privilegiem, em seus estudos, os setores de ponta, tecnologicamente mais desenvolvidos. Aronowitz sublinhou a desvalorização do artesanato na perspectiva dos estudiosos das relações de trabalho (cf. Aronowitz, 1978, p.126).

${ }^{22}$ Michael Taussig constatou, no vale de Cauca, na Colômbia, que os trabalhadores rurais assalariados acreditam poder aumentar a produção e seus ganhos estabelecendo um contrato secreto com o diabo. Mas, nunca o fazem quando trabalham em sua própria terra ou na terra de seus vizinhos, mesmo como assalariados. Crêem, também, que é possível batizar o dinheiro no momento do batismo de uma criança, privando-a, assim, dos efeitos despaganizadores do batismo. Para eles, diz Taussig, "o novo modo de produção (capitalista) é inerentemente crítico e antagônico" (cf. Taussig, 1977, p.130-155). 
23 "Uma aranha executa operações que lembram as do tecelão e uma abelha envergonharia, pela construção das células de sua colméia, mais de um mestre pedreiro. Mas, o que distingue vantajosamente o pior mestre pedreiro da melhor abelha é que o primeiro modelou a célula em seu cérebro antes de construí-la na cera. Ao consumar-se o processo de trabalho surge um resultado que antes dele começar já existia na imaginação do trabalhador, ou seja, idealmente" (cf. Marx, 1982, p.216).

${ }^{24}$ Halbwachs observa que "na sociedade de hoje, o passado deixou muitos traços, visíveis algumas vezes, e que se percebe também na expressão dos rostos, no aspecto dos lugares e mesmo nos modos de pensar e de sentir, inconscientemente conservados e reproduzidos por tais pessoas e dentro de tais ambientes..." (cf. Halbwachs, 1990, p.68).

${ }^{25}$ Poucos anos depois dos acontecimentos aqui examinados, estudando a industrialização e a consciência operária em São Paulo, Touraine observou que "na maioria dos casos, o imigrante reencontra na cidade uma parte de seu meio de origem, seja (...) porque a migração se realiza em família, seja porque o imigrante individual é acolhido, na sua chegada, por vizinhos próximos ou antigos" (cf. Touraine, 1961, p.93). Um bom indício da presença desses valores católicos tradicionais nos dois bairros em que moravam os operários da fábrica está num fato ocorrido alguns anos antes destes acontecimentos: uma menina, por ter falecido poucos dias depois de sua primeira-comunhão, sepultada no chamado Cemitério da Cerâmica, ao lado da fábrica, morreu com fama de santidade. Seu túmulo passou a ser objeto de romarias e promessas e o é ainda hoje. O padre Fabbrini relatoume que, muitas vezes, operárias da Cerâmica, antes de irem para o trabalho, iam à missa e recebiam o sacramento da Eucaristia. Mesmo nestes últimos anos, especialmente em Mauá e em São Bernardo do Campo, descobriu-se a existência de grupos folclóricos inteiros migrados de Minas Gerais e do Nordeste para trabalhar nas fábricas da região industrial do ABC: um grupo de sambalenço e duas folias-de-reis. Grupos idênticos foram localizados em Osasco e na zona leste de São Paulo, na região de São Miguel Paulista. Essas "sobrevivências" sugerem, no mínimo, cautela em relação às certezas definitivas difundidas por certas correntes teóricas que atribuem à cidade e à fábrica um poder de corrosão das culturas tradicionais que não está se confirmando na intensidade suposta.

${ }^{26}$ Para discorrer sobre a crítica da vida cotidiana na própria ação, o autor se inspira justamente em Tempos Modernos, de Chaplin.

${ }^{27}$ A celebração e a oferenda das primícias da produção agrícola foi muito difundida, até há pouco, no Brasil rural. Em parte para evitar o mau-olhado, o caráter maligno do olhar invejoso. Em parte, para evitar que a produção fosse possuída pelas forças do mal e, conseqüentemente, o próprio trabalho fosse alcançado e mutilado pelo maligno (cf. Araújo, s/d, p.117-120). Ritos de benzimento de edifícios na inauguração de empresas eram muito difundidos na localidade, na época destas ocorrências. Mas, o que aconteceu na fábrica não se ligava propriamente ao ato inaugural de tipo urbano e sim à concepção agrária de que a riqueza criada pelo trabalho pode se insurgir contra o trabalhador, se não for simbolicamente oferecida às forças do bem, que se opõem ao mal e o exorcizam preventivamente.

${ }^{28}$ Sobre a antinomia do cotidiano e da festa, cf. Monique Périgord (1977, p.235-254).

${ }^{29}$ Sobre a suspeita nas relações sociais, cf. Boltanski (1973, p.127-147).

${ }^{30}$ Essa concepção influenciou amplamente o desenvolvimento da chamada sociologia fenomenológica, nas suas várias correntes e desdobramentos, especialmente no interacionismo simbólico, de Blumer (cf. 1969). Mas, também na dramaturgia social de Goffman (cf. 1971).

${ }^{31}$ Cf., em especial, Michael T. Taussig (1983) e Laura de Mello e Souza (1987).

${ }^{32}$ Num estudo extremamente interessante sobre o tema, Lefebvre, em referência ao Fausto, de Goethe, diz: "O diabo cumpre as promessas do conhecimento. O conhecimento anuncia e promete a totalidade da vida e da consciência, da natureza e do espírito, do poder e da espontaneidade, da juventude e do saber, e, ainda, a da alegria e da lucidez, da poesia e da inocência" (cf. Lefebvre, 1962, p.68).

${ }^{33} \mathrm{Na}$ análise do fetichismo da mercadoria, Marx já havia assinalado que ela "é um objeto endemoninhado, rico em sutilezas metafísicas e reticências teológicas". E acrescentou: "O misterioso da forma mercantil consiste, simplesmente, em que a mesma reflete ante os homens o caráter social de seu próprio trabalho como caracteres objetivos inerentes aos produtos do trabalho, como propriedades sociais naturais de ditas coisas e, portanto, em que também reflete a relação social que 
medeia entre os produtores e o trabalho global, como uma relação social entre objetos, existente à margem dos produtores" (cf. Marx, 1982, p.87-88).

\section{REFERÊNCIASBIBLIOGRÁFICAS}

AraúJo, Alceu Maynard. (s/d) Folclore nacional. Vol. III, 2a edição. São Paulo, Edições Melhoramentos.

Aronowitz, Stanley. (1978) Marx, Braverman, and the logic of capital. In: __ . The insurgent sociologist. Vol. VIII, nos 2-3. Eugene, University of Oregon, fall.

Berger, Peter L. (1972) Perspectivas sociológicas. Trad. de Donaldson M. Garschagen. Petrópolis, Ed. Vozes.

Blumer, Herbert. (1969) Symbolic Interactionism. Englewood Cliffs, PrenticeHall, Inc.

Boltanski, Luc. (1973) Erving Goffman et le temps du soupçon. In: Social Science Information. XII-3. The Hague, International Social Science Council, Mouton \& Co., June.

BraVerman, Harry. (1981) Trabalho e capital monopolista. A degradação do trabalho no século XX. Trad. de Nathanael C. Caixeiro, 3ㄹe edição. Rio de Janeiro, Zahar Editores.

CASTALdi, Carlos. (1957) A aparição do demônio no Catulé. In: QueIroz, Maria Isaura et alii. Estudos de sociologia e história. São Paulo, Editora Anhembi Limitada, São Paulo.

FouCAult, Michel. (1975) Surveiller et punir. Naissance de la prison. Paris, Éditions Gallimard.

. (1982) Microfísica do poder. Organização, introdução e revisão técnica de Roberto Machado, $3^{a}$ edição. Rio de Janeiro, Editora Graal.

French, John D. (1992) The brazilian workers' ABC. Class conflict and alliances in modern São Paulo. Chapel Hill, The University of North Carolina Press.

GoFFMAN, Erving. (1971) La presentación de la persona en la vida cotidiana. Trad. de Hildegarde B. Torres Perrén e Flora Setaro. Buenos Aires, Amorrortu Editores.

GoRz, André. (1964) Historia y enajenación. Trad. de Julieta Campos. México, Fondo de Cultura Económica.

Guterman, Norbert \& Lefebvre, Henri. (1979) La conscience mystifiée. Paris, Sycomore.

Halbwachs, Maurice. (1990) A memória coletiva. Trad. de Laurent Léon 
Schaffter. São Paulo, Ed. Vértice.

Lefebvre, Henri. (1957) La pensée de Lenine. Paris, Bordas.

. (1958) Critique de la vie quotidienne. Vol. I. Paris, L'Arche Éditeur. - (1962) Les metamorphoses du diable. In: Introduction à la modernité. Paris, Les Éditions de Minuit.

. (1973) La survie du capitalisme (la re-production des rapportes de production). Paris, Éditions Anthropos.

. (1978) De l'État. Tomo IV. Paris, Union Générale d'Éditions.

Lopes, José Sergio Leite. (1988) A tecelagem dos conflitos de classe na cidade das chaminés. São Paulo, Editora Marco Zero.

LoPEs, Juarez Rubens Brandão. (1964) Sociedade industrial no Brasil. São Paulo, Difusão Européia do Livro.

. (1967) Crise do Brasil arcaico. São Paulo, Difusão Européia do Livro.

MACEDO, Carmen Cinira. (1979) A reprodução da desigualdade. O projeto de vida familiar de um grupo operário. São Paulo, Hucitec.

Marshall, T. H. (1967) Cidadania, classe social e status. Trad. de Meton Porto Gadelha. Rio de Janeiro, Zahar Editores.

MARX, Karl. (1971) El Capital, Libro I . Capitulo VI, Inedito. Buenos Aires, Ediciones Signos.

. (1981) El Capital. Crítica de la economía política. Libro primero, tomo I, vol. 2. Trad. de Pedro Scaron. México, Siglo Veinteuno Editores.

. (1982) El Capital. Crítica de la economía política, Libro primero, tomo I, vol. 1. Trad. de Pedro Scaron. México, Siglo Veinteuno Editores.

Mercadante, Aloizio (org.). (1987) Imagens da luta. São Bernardo do Campo, Sindicato dos Trabalhadores nas Indústrias Metalúrgicas, Mecânicas e de Material Elétrico de São Bernardo do Campo e Diadema.

Munhoz, Fábio Antônio. (s/d) Sindicalismo e democracia populista: a greve de 1957 .(mimeo). São Paulo, CEDEC.

Pereira, Vera Maria Candido. (1979) O coração da fábrica. Estudo de caso entre operários têxteis. Rio de Janeiro, Ed. Campus.

PÉRIGORD, Monique. (1977) Henri Lefebvre ou les moments de la quotidienneté. In: Revue de Synthèse. Tome XCVIII, no 87/88. Paris, juillet/ décembre.

SCHNEIDER, Eugene V. (1957) Industrial sociology. The social relations of industry and the community. New York, McGraw-Hill Book Company, Inc. 
MARTINS, José de Souza. A aparição do demônio na fábrica, no meio da produção. Tempo Social; Rev. Sociol. USP, S. Paulo, 5(1-2): 1-29, 1993 (editado em nov. 1994).

Simonsen, Roberto C. (1973) Evolução industrial do Brasil e outros estudos. Seleção, notas e bibliografia de Edgard Carone. São Paulo, Cia. Editora Nacional/EDUSP.

SouzA, Laura de Mello e. (1987) O diabo e a terra de Santa Cruz. Feitiçaria e religiosidade popular no Brasil colonial. São Paulo, Companhia das Letras.

TAUSSIG, Michael. (1977) The genesis of capitalism amongst a South American peasantry: Devil's labor and the baptism of money. In:

Comparative studies in society and history. Vol. 19, ํㅡㄹ. Cambridge, Cambridge University Press, April.

. (1983) The devil and commodity fetishism in South America. Chapel Hill, The University of North Carolina Press.

Thompson, Edward P. (1979) Tradición, revuelta y consciencia de clase. Trad. de Eva Rodriguez. Barcelona, Editorial Crítica.

TouraINE, Alain. (1961) Industrialisation et conscience ouvrière à São Paulo. In: _. Sociologie du Travail. Troisième année, no 4/61. Paris, Éditions du Seuil. 